\title{
Analisa Pengaruh Jumlah Penduduk, Produk Domestik Regional Bruto (PDRB), dan Upah Minimum Kabupaten/Kota terhadap Tingkat Pengangguran Terbuka di Kabupaten/Kota di Provinsi Jawa Timur Tahun 2012-2018
}

\author{
Edo Permadi, Eko Chrystanto \\ Program Studi Ekonomi Pembangunan FEB Universitas Wijaya Kusuma Surabaya \\ Email: edopermadi98@gmail.com
}

\begin{tabular}{l}
\hline \hline Article Info \\
\hline Article history: \\
Published: June 28,2021 \\
Page: $86-95$ \\
\hline
\end{tabular}

Keyword:

Jumlah Penduduk, Produk

Domestik Regional Bruto

(PDRB), Upah

Minimum

Kabupaten/Kota, dan

Tingkat Pengangguran

Terbuka.

\section{Abstract}

Penelitian ini bertujuan untuk menganalisis pengaruh Jumlah Penduduk terhadap Tingkat Pengangguran Terbuka, menganalisis pengaruh Produk Domestik Regional Bruto (PDRB) terhadap Tingkat Pengangguran Terbuka, menganalisis Upah Minimum Kabupaten/Kota terhadap Tingkat Pengangguran Terbuka di Kabupaten/Kota di Jawa Timur. Metode analisis yang digunakan pada penilitian ini menggunakan teknik, analisis regresi linear berganda. Hasil penelitian ini menunjukkan bahwa secara parsial dan simultan Jumlah Penduduk, Produk Domestik Regional Bruto (PDRB) Upah Minimum Kabupaten/ Kota berpengaruh signifikan terhadap Tingkat Pengangguran Terbuka di 38 Kabupaten/Kota di Jawa Timur

Kata Kunci : Jumlah Penduduk, Produk Domestik Regional Bruto (PDRB), Upah Minimum Kabupaten/Kota, dan Tingkat Pengangguran Terbuka.

\section{Pendahuluan}

Tingkat pengangguran terbuka mempunyai arti yaitu pengangguran yang dialami tenaga kerja yang sungguh sungguh tidak mempunyai pekerjaan. Pengangguran ini memang jenis pengangguran yang bisa di bilang cukup banyak, karena memang belum mendapatkan pekerjaan meskipun sudah berusaha dengan maksimal untuk mencari pekerjaan yang semua hal itu disebabkan karena petumbuhan penambahan tenaga kerja lebih tinggi dari pada pertumbuhan lapangan pekerjaan dampak dari situasi sepeeti ini mereka tidak melakukan suatu pekerjaan, jadi pengangguran yang dilihat itu sangat nyata oleh karena itu disebut dengan pengangguran terbuka. Penurunan pertumbuhan ekonomi menjadi salah suatu

\section{Editorial Office:}

Prodi Ilmu Ekonomi Fakultas Ekonomi dan Bisnis Islam, UIN Sunan Ampel Surabaya

Jl. Ahmad Yani 117 Surabaya, Jawa Timur 60237, Indonesia.

Email: oje@uinsby.ac.id 
sebab terjadinya pengangguran terbuka, sebab lainnya anatra lain, kemunduran perkambangan suatu industri, kemajuan teknologi yang secara langsung mengurangi dan menggantikan tenaga manusia (Sukirno, 2000).

Jawa Timur adalah salah satu provinsi di Pulau Jawa yang memiliki jumlah penduduk paling banyak kedua setelah Jawa Barat dengan jumlah penduduk pada tahun 2018 mencapai 39,5 Juta jiwa. Banyaknya jumlah penduduk jika tidak diikuti dengan pertumbuhan ekonomi akan menyebabkan berbagai masalah salah satu contohnya adalah pengangguran. Masalah klasik ini sangat erat hubungannya dengan banyaknya jumlah penduduk, karena setiap penduduk mempunyai kebutuhan yang harus dicukupi, pencukupan kebutuhan memakai alat yang disebut uang, uang jika tidak bekerja akan tidak bisa mendapatkan lingkaran inilah yang membuat jika banyaknya jumlah penduduk tidak diikuti dengan pertumbuhan ekonomi atau pertumbuhan lapangan pekerjaan akan menyebabkan masalah penganguran ini sulit untuk diatasi.

Kondisi ekonomi dalam suatu wilayah mempunyai kapasitas yang berbeda beda tergantung fokus pembangunan dan potensi tiap daerah khususnya di Jawa Tmur, pengukuran atau indikator dalam menilai kondisi ekonomi suatu daerah adalah dengan melihat Produk Domestik Regional Bruto di masing-masing daerah, semakin besar nilai PDRB maka bisa diartikan semakin baik pula kondisi ekonomi di wilayah tersebut, kondisi ekonomi di suatu wilyah itu baik dominan disebabkan oleh pembangunan ekonomi di wilayah tersebut digencarkam, pembanguanan di suatu wilayah akan dapat menyerap tenaga kerja sehinggan nantinya dapat menurunkan tingkat pengangguran di suatu wilayah

Dalam pemenuhan kebutuhan setiap individu harus bekerja dan imbal hasil dari pekerjaan yang sudah dilakukan adalah upah. Menurut (Sukirno, 2005) definisi upah adalah sebagai pembayaran yang diperoleh dari berbagai macam bentuk jasa yang tersedia yang diberikan oleh para tenaga kerja kepada para pengusaha yang secara spesifik membutuhkan untuk memenuhi faktor produksi perusahaannya. Di Indonesia diterapkan nominal pengupahan yang berbeda beda di setiap wilayah tergantung pembangunan di masing-masing wialayah. Upah ini adalah faktor kunci kenapa individu ingin bekerja karena ingin mendapatkan uang sebagai alat pemenuhan kebuthan. Hal ini sebenarnya adalah salah satu faktor untuk menekan tingkat pengangguran

Berdasarkan pada penelitian yang telah dipaparkan dapat disimpulkan pada judul penelitian ini adalah Pengaruh Jumlah Penduduk, Produk Domestik Regional Bruto (PDRB), dan Upah Minimum Kabupaten/Kota tehadap Tingkat Pengangguran Terbuka di Kabupaten/Kota di Jawa Timur Tahun 2012-2019. Rumusan masalah dalam penelitian ini adalah (1) Apakah Jumlah Penduduk, Produk Domestik Regional Bruto (PDRB), dan Upah Minimum Kabupaten/Kota (UMK) berpengaruh secara simultan terhadap tingkat pengangguran terbuka di 38 Kabupaten/Kota di Provinsi Jawa Timur Tahun 2012 - 2018 (2) Apakah Jumlah Penduduk, Produk Domestik Regional Bruto (PDRB), dan Upah Minimum Kabupaten/Kota (UMK) berpengaruh secara parsial terhadap tingkat pengangguran terbuka di 38 Kabupaten/Kota di Provinsi Jawa Timur 2012 - 2018 (3) Variabel manakah diantara Jumlah Penduduk, Produk Domestik Regional Bruto (PDRB), dan Upah Minimum Kabupaten/Kota (UMK) yang mempunyai pengaruh dominan terhadap tingkat pengangguran terbuka di 38 Kabupaten/Kota di Provinsi Jawa Timur tahun $2012-2018$.

\section{Kajian Pustaka}

Tingkat pengangguran terbuka mempunyai arti yaitu pengangguran yang dialami tenaga kerja yang sungguh sungguh 
tidak mempunyai pekerjaan. Pengangguran ini memang jenis pengangguran yang bisa dibilang cukup banyak, karena memmang belum mendapatkan pekerjaan meskipun sudah berusaha dengan maksimal untuk mencari pekerjaan yang semua hal itu disebabkan karena petumbuhan penambahan tenaga kerja lebih tinggi dari pada pertumbuhan lapangan pekerjaan dampak dari situasi sepeeti ini mereka tidak melakukan suatu pekerjaan, jadi pengangguran yang dilihat itu sangat nyata oleh karena itu disebut dengan pengangguran terbuka. Penurunan pertumbuhan ekonomi menjadi salah suatu sebab terjadinya pengangguran terbuka, sebab lainnya anatra lain, kemunduran perkambangan suatu industri, kemajuan teknologi yang secara langsung mengurangi dan menggantikan tenaga manusia (Sukirno, 2000). Menurut (Kuncoro,2006) pengangguran terbuka biasanya banyak terjadi pada generasi muda fresh graduate yang baru selesai menamatkan pendidikan menengah dan tinggi. Dalam prakteknya para generasi muda ini cenderung mencari pekerjaan yang pas dengan apa yang dikehendaki yang sesuai dengan aspirasi mereka dan rata rata aspirasi mereka adalah bekerja di kantor dan di sektor modern, maka dari itu mereka mau dan bersedia menunggu untuk waktu yang lama. Jika daerah tempoat mereka tinggal tidak menyediakan apa yang mnejadi aspirasi mereka, mereka lebih memilih untuk mencari pekerjaan di luar dari daerah tempat mereka tinggal ke daerah yang kegiatan industri di sektor modern berkembang walaupun dengan tingkat pengangguran disana juga cukup tinggi, sebaliknya tidak seperti daerah dengan perkamangan industri yang pesat di daerah tingkat pengangguran cenderung rendah karena mereka yang berpenddikan rendah berssedia bekerja apasaja untuk menopang kehidupan, apabila sektor agraria atau pertanian kurang dapat menjamin kehidupan mereka, mereka masyarakat daerah bersedia untuk bekerja pada sektor infromal, mereka tidak memperdulikan pengahsilan yang mereka dapat rendah atau jam kerja yang tidak sesuai ddenganaturan yang paling penting adalah uang yang didapat dari pekerjaan tersebut

Semakin tahun peningkatan jumlah penduduk mengalami kenaikan yang tinggi, bertambahnya jumlah penduduk akan selalu di barengi dengan munculnya masalah masalah yang diakibatkan pertumbuhan jumlah penduduk yang dinamis. Pertumbuhan penduduk yang tinggi serta meningkatnya kegiatan dan aktifitas di beberapa sektor menimbulkan masalah masalah di berbagai wilayah yang umum terjadi di Indonesia Menurut (Sukirno, 2006) yang mengutip dari pendapat Nelson dan Leibsten menerangkan bahwa terdapat pengaruh langsung antara penamabahan jumlah penduduk terhadap tingkat kesejahteraan masyarakat, lebih lagi Nelson dan Leibsten menunjukkan bahwa pertumbuhan jumlah penduduk yang signifikan di negara negara berkembang menyebabakan tingkat kesejahteraan masyarakat sulit mengalami perbaikan yang berarti dalam jangka panjangnya akan menurunkan tingkat kesejahteraan masyarakat serta tingkat jumlah masyarakat miskin.

Peningkatan jumlah penduduk yang terlalu tinggi menyababkan penghambatan proses pembangunan ekonomi di negara sedang berkembang. Pendapatan perkapita yang rendah dan tingkat pengumpulan modal yang renmdah akan semakin menyulitkan negara berkambang untuk menopang ledakan penambahan jumlah penduduk, walaupun output produksi meningkat sebagai hasil kemajuan teknologi yang lebih baik, peningkatan ini akan di makan dan tidak kentara karena disebabkan pertumbuhan jumlah penduduk yang terlalu besar, alhasill tidak ada perbaikan siginifikan dalam laju pertumbuhan yang nyata bagi perekonomian negara (Jhingan, 2003) 
Menurut BPS Produk Domestik Regional Bruto adalah salah satu indikator kondisi ekonomi di suatu negara atau wilayah dalam suatu periode tertentu baik atas dasar harga berlaku maupun harga konstan. Pada dasarnya PDRB adalah jumlah nilai tambah yang dihasilkan oleh seluruh unit usaha dalam suatu negara atau merupakan jumlah nilai barang dan jasa akhir yang dihasilkan oleh seluruh unit ekonomi di negara tersebut PDRB atas dasar harga konstan menujukkan nilai tambah nilai tambah barang dan jasa yang dihitung menggunakan harga dasar pada tahun tertentu sebagai acuan, sedangkan PDRB atas harga berlaku menggambarkan nilai tambah barang dan jasa yang dihitung menggunakan harga yang berlaku pada setiap tahun tidak mengacu pada harga di tahun tertentu sepeeti PDRB atas dasar haga konstan. Ditinjau pada fungsinya PDRB atas dasar harga Konstan dan hrga berlaku mempunyai fungsinya masing masing, untuk PDRB atas harga konstan digunakan untuk mengetahui pertumbuhan ekonomi pada suatu periode ke periode (tahun ke tahun atau triwulan ke triwulan), dan kegunaan PDRB atas dasar harga berlaku dapat digunakan untuk melihat pergeseran dan struktur ekonomi

Tenaga kerja adalah faktor produksi yang dianggap paling penting kedua setelah bahan baku produksi, karena melalui jasa tenaga kerja inilah sumber daya alam dapat dirubah menjadi bahan jadi yang bernilai untuk memenuhi kebutuhan manusia, oleh karena itu atas pekerjaan yang dilakukannya tenaga kerja berhak mendapatkan balas jasa dari perushaan atau bos yang membawahinya berupa penghasialn yang disebut upah Secara umum upah dimaknai sebagai harga yang di bayarkan kepada pekerja karena jasanya dalam produksi kekayaan layaknya seperti faktor produksi lainnya. Upah adalah imbalan atas jasa yang diberikan oleh para tenaga kerja untuk perushaan yang dinaunginya. Menurut (Sukirno, 2005) definisi upah adalah sebagai pembayaran yang diperoleh dari berbagai macam bentuk jasa yang tersedia yang diberikan oleh para tenaga kerja kepada para pengusaha yang secara spesifik membutuhkan untuk memenuhi faktor produksi perusahaannya. Sedangkan menurut (Gilarso, 2003) menjelaskan upah adalah balas karya untuk faktor produksi tenaga kerja yang dalam lingkup luas mencakup gaji, uang lembur, tunjangan, honorarium, dan bentuk balas jasa berbentuk upah menurut kebutuhan perusahaan masing masing

Sedangkaan Upah Minimum adalah upah yang menjadi suatu standar minium pemberia upah yang digunakan oleh para pelaku usaha, pemIlik modal, Pelaku industri, yang mmberikan upah atau gaji yang berada dalam lingkup perushaanya atau lingkungan kerjanya (Purnami, 2015). Tujuan dari penetapan upah minimum kabupaten atau kota agar supaya para pekerja ini dapat memperoleh penghasilan yang layak sebagai balas jasa aats tenaga yang diberikan oleh tanaga kerja kepada pihak perusahaannya yang menggunakan jasanya

\section{Metode Penelitian}

Pendeketan penelitian ini menggunakann penelitian deskriptif kuantitatif. Deskriptif kuantitatif merupakan analisis yang menggunakan perhitungan angka dan juga hipotesis serta data yang harus dapat diukur. Penelitian ini menggunaakn variabel dependen dan variabel independen, yang terdapat dalam variabel independen yaitu Jumlah Penduduk, Produk Domestik Regional Bruto (PDRB), Upah Minimum Kabupaten/Kota dan variabel dependern adalah Tingkat Pengangguran Terbuka. Model dasar yang akan digunakan dalam penelitian ini adalah sebagai berikut:

TPTit $=\beta 0+\beta 1$ JPDit $+\beta 2$ PRBit $+\beta 3$ UMKit cit 
Keterangan :

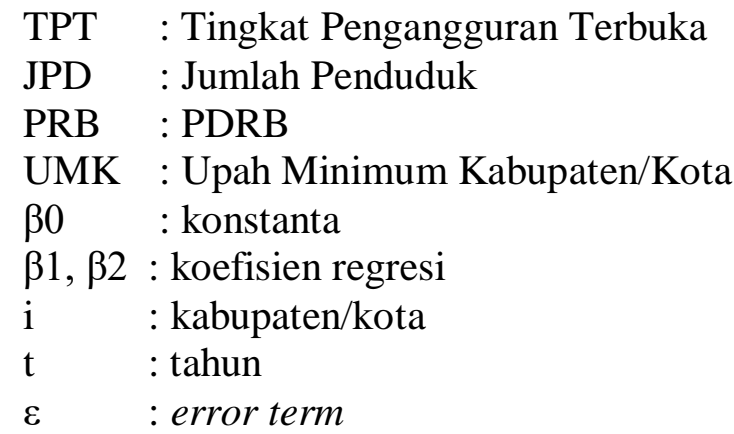

\section{Hasil dan Pembahasan}

Uji Asumsi Klasik

\section{Uji Normalitas}

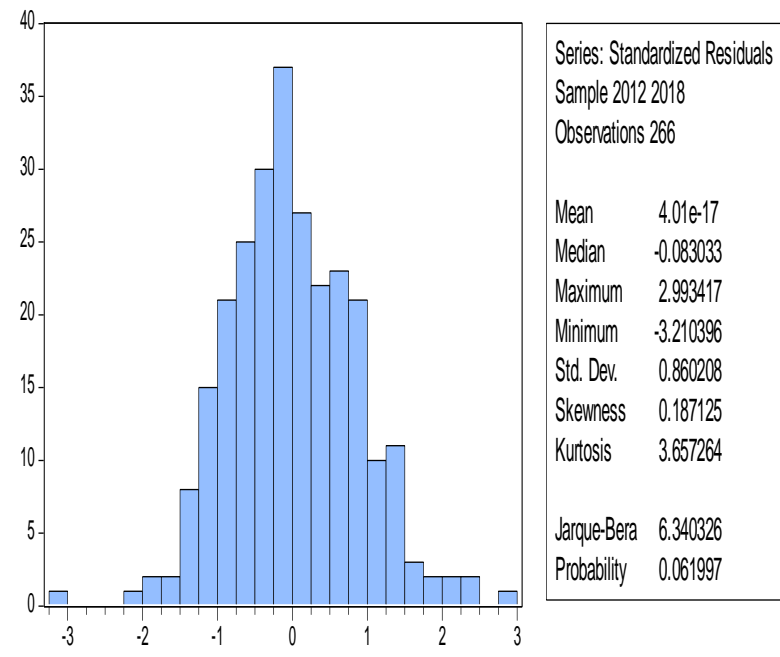

Sumber gambar : Hasil Output Eviews 2020 Gambar 1 Normality Test

Dari hasil uji normalitas di atas diperoleh nilai probabilitas sebesar 0.061 , dengan tingkat signifikansi sebesar 5\% maka 0.061 $>0.05$ artinya terima $\mathrm{H} 0$ sehingga dapat disimpulkan data dalam penelitian ini berdistribusi normal

\section{Uji Multikolinearitas}

Tabel 1 Uji Multikolinearitas

Sumber Data: Hasil Output Eviews 2020

Berdasarkan tabel di atas, didapatkan nilai correlations masing-masing variabel. Dengan asumsi nilai correlation $<0.9$ maka dapat disimpulkan bahwa tidak terjadi

\begin{tabular}{|c|c|c|c|}
\hline & JPD & PRB & UMK \\
\hline JPD & 1.000000 & 0.661987 & 0.390744 \\
\hline PRB & 0.661987 & 1.000000 & 0.556767 \\
\hline UMK & 0.390744 & 0.556767 & 1.000000 \\
\hline
\end{tabular}

multikolinearitas

\section{Uji Heterokedastisitas}

H0: tidak ada masalah heteroskedastisitas H1: ada masalah heteroskedastisitas Tabel 2 Uji Heterokedastisitas

\begin{tabular}{|c|c|}
\hline Variable & Prob. \\
\hline C & 0.3025 \\
\hline JPD & 0.4703 \\
\hline PRB & 0.5773 \\
\hline UMK & 0.5004 \\
\hline
\end{tabular}

Sumber Data: Hasil Output Eviews 2020

Berdasarkan tabel di atas, didapatkan nilai uji hesteroskedastisitas yang dapat dilihat dari nilai probabilitas masing-masing variabel independen secara berturut-turut yaitu sebesar 0.4703, 0.5773, dan 0.5004, dengan tingkat signifikansi sebesar 5\% maka nilai probabilitas $>0.05$ artinya terima $\mathrm{H} 0$ sehingga dapat disimpulkan tidak terjadi masalah heterokedastisitas di dalam penelitian ini.

Uji Autokorelasi

Tabel 3 Uji Autokorelasi

\begin{tabular}{|c|c|}
\hline Hasil Uji DW & Nilai \\
\hline Durbin-Watson stat & 1.830622 \\
\hline
\end{tabular}

Sumber Data: Hasil Output Eviews 2020

Dari tabel di atas diperoleh nilai durbin-watson diperoleh sebesar 1.8306, dengan nilai dW dan dU sebesar 1.7382 dan 1.7990 dengan demikian nilai $1.830>1.799$ sehingga tidak terjadi autokorelasi di dalam penelitian ini. 
Uji Linearitas

Tabel 4 Uji Linearitas

\begin{tabular}{|c|}
\hline Sig Deviation From Linearity \\
\hline, 057 \\
\hline, 000 \\
, 083 \\
\hline
\end{tabular}

Sumber Data : Hasil Output SPSS 2021

Berdasarkan hasil uji linieritas di atas dikertahui bahwa nilai sig deviation 0,083 lebih besar dari pada 0,05 maka dapat disimpulkan bahwa terdapat hubungan yang linier antara Variabel dependen variabel independen

Tabel 5 Model Data Panel

\begin{tabular}{|c|r|r|r|r|}
\hline Variable & Coefficient & $\begin{array}{r}\text { Std. } \\
\text { Error }\end{array}$ & t-Statistic & Prob. \\
\hline C & -3.264941 & 5.116358 & -0.638138 & 0.5240 \\
\hline JPD & $7.83 \mathrm{E}-06$ & $5.30 \mathrm{E}-06$ & 2.476942 & 0.0141 \\
\hline PRB & $1.24 \mathrm{E}-05$ & $1.03 \mathrm{E}-05$ & 2.198060 & 0.0232 \\
\hline UMK & $-6.78 \mathrm{E}-07$ & $2.53 \mathrm{E}-07$ & -2.678027 & 0.0080 \\
\hline
\end{tabular}

Sumber Data: Hasil Output Eviews 2020

Berdasarkan tabel di atas, diperoleh estimasi untuk masing-masing model regresi data panel pada penelitian ini. Berikut persamaan model regresi data panel dalam penelitian ini:

$$
\begin{aligned}
\text { TPT }_{\text {it }}= & -3.264941+7.83006 \mathrm{JPD}_{\text {it }}+ \\
& 1.24006 \mathrm{PRB}_{\mathrm{it}}-6.78007 \mathrm{UMK}_{\mathrm{it}}+ \\
& \varepsilon_{\mathrm{it}}
\end{aligned}
$$

Interpretasi dari model persamaan regresi sebagai berikut:

a. Konstanta $=-3.26$

Konstanta sebesar -3.26 dapat disimpulkan apabila variabel independen bernilai konstan maka variabel TPT akan bernilai sebesar 3.26 .

b. Koefisien JPD $=7.83$

Koefisien JPD sebesar 7.83 dapat disimpulkan bahwa jumlah penduduk memberikan pengaruh positif sebesar 7.83 terhadap tingkat penggangguran terbuka jika variabel lainnya bernilai tetap atau semakin tinggi jumlah penduduk maka tingkat pengangguran terbuka juga semakin tinggi.

c. Koefisien PRB $=1.24$

Koefisien PRB sebesar 1.24 dapat disimpulkan bahwa produk regional bruto memberikan pengaruh positif sebesar 1.24 terhadap tingkat penggangguran terbuka jika variabel lainnya bernilai tetap atau semakin tinggi prb maka tingkat pengangguran terbuka juga semakin tinggi.

d. Koefisien UMK $=-6.78$

Koefisien UMK sebesar -6.78 dapat disimpulkan bahwa upah minimum kota memberikan pengaruh negatif sebesar -6.78 terhadap tingkat penggangguran terbuka jika variabel lainnya bernilai tetap atau semakin tinggi upah minimum kota maka tingkat pengangguran terbuka semakin rendah.

\section{Pengujian Signifikan}

\section{Uji F}

H0:Tidak ada pengaruh variabel independen secara simultan terhadap dependen

H1:Ada pengaruh variabel independen terhadap secara simultan dependen

Tabel 6 Uji F

\begin{tabular}{|c|c|}
\hline F-statistic & 12.97189 \\
\hline Prob(F-statistic) & 0.000000 \\
\hline
\end{tabular}

Sumber Data: Hasil Output Eviews 2020

Dari tabel di atas diperoleh nilai fstatistic sebesar 12.97189 dengan nilai probabilitas sebesar 0.000 . Dengan tingkat signifikansi sebesar 5\% maka $0.000<0.05$ artinya tolak $\mathrm{H} 0$ sehingga dapat disimpulkan bahwa ada pengaruh variabel Jumlah Penduduk, Produk Regional Bruto, dan Upah Minimum Kota secara simultan terhadap Tingkat Penggangguran Terbuka. Uji t

Tabel 7 Uji t

\begin{tabular}{|c|c|}
\hline Variable & Prob. \\
\hline $\mathrm{C}$ & 0.5240 \\
\hline
\end{tabular}




\begin{tabular}{|c|c|}
\hline JPD & 0.0141 \\
\hline PRB & 0.0232 \\
\hline UMK & 0.0080 \\
\hline
\end{tabular}

Sumber Data: Hasil Output Eviews 2020

1. JPD $\rightarrow$ TPT (Pengaruh Jumlah Penduduk Terjadap Tingkat Pengangguran Terbuka) H0: Tidak ada pengaruh Jumlah Penduduk terhadap Tingkat Pengangguran Terbuka H1: Ada pengaruh Jumlah Penduduk terhadap Tingkat Pengangguran Terbuka Diperoleh nilai probabilitas sebesar 0.0141 dengan tingkat signifikansi sebesar 0.05 maka $0.0141<0.05$ artinya $\mathrm{H} 0$ ditolak dan H1 diterima sehingga dapat disimpulkan terdapat pengaruh yang signifikan antara variabel jumlah penduduk terhadap tingkat pengangguran terbuka.

2. PRB $\rightarrow$ TPT (Pengaruh PDRB Terjadap Tingkat Pengangguran Terbuka)

H0: Tidak ada pengaruh Produk Regional Bruto terhadap Tingkat Pengangguran Terbuka

H1: Ada pengaruh Produk Regional Bruto terhadap Tingkat Pengangguran Terbuka Diperoleh nilai probabilitas sebesar 0.0232 dengan tingkat signifikansi sebesar 0.05 maka $0.0232<0.05$ artinya $\mathrm{H} 0$ ditolak dan H1 diterima sehingga dapat disimpulkan terdapat pengaruh yang signifikan antara variabel produk regional bruto terhadap tingkat pengangguran terbuka.

3. UMK $\rightarrow$ TPT (Pengaruh Upah Minimum Kabupaten/Kota Terhadap Tingkat Pengangguran Terbuka)

H0: Tidak ada pengaruh Upah Minimum Kota terhadap Tingkat Pengangguran Terbuka

H1: Ada pengaruh Upah Minimum Kota terhadap Tingkat Pengangguran Terbuka Diperoleh nilai probabilitas sebesar 0.0080 dengan tingkat signifikansi sebesar 0.05 maka $0.0080<0.05$ artinya $\mathrm{H} 0$ ditolak dan $\mathrm{H} 1$ diterima sehingga dapat disimpulkan terdapat pengaruh yang signifikan antara variabel upah minimum kota terhadap tingkat pengangguran terbuka

\section{Koefisien Determinasi}

Tabel 8 Uji R ${ }^{2}$

\begin{tabular}{|c|c|}
\hline Koefisien Determinasi $\mathrm{R}^{2}$ & Nilai Koefisien \\
\hline R-squared & 0.697530 \\
\hline
\end{tabular}

Sumber Data : Hasil Output Eviews 2020

Diperoleh nilai r-squared sebesar 0.697 atau sebesar $69.7 \%$ variabel Tingkat Pengangguran Terbuka dapat diterangkan oleh Jumlah Penduduk, Produk Regional Bruto dan Upah Minimum Kota sedangkan sisanya sebesar $30.3 \%$ diterangkan oleh variabel lain yang tidak terdapat dalam penelitian ini.

\section{Pembahasan}

Pengaruh Jumlah Penduduk terhadap Tingkat Pengangguran Terbuka di Provinsi Jawa Timur

Berdasarkan hasil dari pengolahan data menunjukkan bahwa nilai probabilitas variabel Jumlah Penduduk sebesar 0.0141 yang berarti lebih kecil dari 0,05 , jadi $\mathrm{H} 0$ ditolak dan H1 diterima sehingga Jumlah Penduduk memiliki pengaruh terhadap tingkat pengangguran, sedangkan nilai koefisien regresi variabel Jumlah Penduduk sebesar 7.83006 hal ini berarti jika terdapat perubahan jumlah penduduk sebesar $1 \%$ maka akan menyebabkan perubahan peningkatan terjadap tingkat pengangguran terbuka sebesar $7.83 \%$

Penelitian ini sejalan dengan penelitian yang di lakukakan Muminin dan Rianto tahun (2017) yang berjudul Pengaruh Pertumbuhan Ekonomi Dan Jumlah Penduduk Terhadap Tingkat Pengangguran Terbuka Di Kabupaten/Kota Provinsi Jawa Timur Tahun 2011-2015 yang menjelaskan bahwa jumlah penduduk berpengaruh positif dan signifikan terhadap tingkat pengan gguran terbuka, hal ini dikarenakan bertambahnya jumlah penduduk dalam suatu wilayah dengan tingkat angkatan kerja yang semakin tinggi pula dengan tanpa 
dibarengi undlapangan pekerjaan baru maka akan bertambah tinggi pula tingkat pengangguran di wilayah tersebut

\section{Pengaruh Produk Domestik Regional Bruto terhadap Tingkat Pengangguran Terbuka di Provinsi Jawa Timur}

Berdasarkan hasil dari pengolahan data menunjukkan bahwa nilai probabilitas variabel Produk Domestik Regional Bruto sebesar 0.0232 yang berarti lebih kecil dari 0,05, jadi $\mathrm{H} 0$ ditolak dan $\mathrm{H} 1$ diterima sehingga Produk Domestik Regional Bruto memiliki pengaruh terhadap tingkat pengangguran, sedangkan nilai koefisien regresi variabel Produk Domestik Regional Bruto sebesar 1.24006 hal ini berarti jika terdapat perubahan Produk Domestik Regional Bruto sebesar $1 \%$ maka akan menyebabkan perubahan peningkatan terjadap tingkat pengangguran terbuka sebesar $1.24 \%$

Penelitian ini sejalan dengan dengan penelitian yang dilakukan Mahroji dan Anwar (2020) yang berjudul Pengaruh Jumlah Penduduk, PDRB, dan Indeks Pembangunan Manusia (IPM) Terhadap Tingkat Penganguran di Provinsi Jawa Tengah yang menjelaskan bahwa Produk domestik regional bruto mempunyai pengaruh yang positif signifikan terhadap tingkat pengangguran terbuka, karena diakibatrkan tidak semua tenaga kerja bisa terserap dalam kaitanya dengan pertumbuhan ekonomi, sehingga meskpu $n$ laju pertumbuhan ekonomi ekonomi mengalami peningkatan akan tetapi malah memberikan efek peningkatan terhadap pengangguran terbuka.

\section{Pengaruh Upah Minimum Kabupaten/Kota terhadap Tingkat Pengangguran Terbuka di Provinsi Jawa Timur}

Berdasarkan hasil dari pengolahan data menunjukkan bahwa nilai probabilitas variabel Jumlah Penduduk sebesar 0.0080 yang berarti lebih kecil dari 0,05 , jadi HO ditolak dan $\mathrm{H} 1$ diterima sehingga Upah Minimum Kabupen/Kota memiliki pengaruh terhadap tingkat pengangguran, sedangkan nilai koefisien regresi variabel Upah Minimum Kabupaten/Kota sebesar 6.78007 hal ini berarti jika terdapat perubahan Upah Minimum Kabupaten/Kota sebesar $1 \%$ maka akan menyebabkan perubahan penurunan terhadap tingkat pengangguran terbuka sebesar $-6.78 \%$. Penurunan tingkat pengangguran terbuka karena perubahan upah minimum sebesar $1 \%$ mempunyai dampak yang signifikan pada tingkat pengangguran terbuka yang mencapai penurunan presentase -6.78 , hal itu dikarenakan pada periode tahun 20122018 banyak jenis jenis pekerjaan baru yang sejalan dengan perkembangan zaman, dan pada akhirnya jenis jenis pekerjaan baru ini menghasilkan output yang dapat dirasakan masyarakat,dalam membantu meringankan kegiatan keseharian masyarakat yang pada akhirnya akan membuat masyarakat mempunyai jenis jenis pengeluaran baru. korelasi ini yang membuat tingkat upah akan dapat menekan tingkat pengangguran terbuka pada masyarakat, karena semakin besar upah gaya hidup dan kebutuhan masyarakat akan juga meningkat.

Penelitian ini sejalan dengan penelitian Khoirulana (2017) dengan judul penelitian Analisis Pengaruh Jumlah Penduduk, Produk Domestik Regional Bruto (PDRB), Upah Minimum Kabupaten/Kota (UMK), dan Inflasi Terhadap Tingkat Pengangguran Terbuka di Provinsi Jawa Tengah Periode Tahun 2011-2015 yang menerangkan bahwa Upah Minimum Kabupaten/Kota berpengaruh signifikan negatif terhadap Tingkat Pengangguran Terbuka.

\section{Kesimpulan}

Berdasarkan hasil dari analisis statistik serta pembahasan untuk menguji hipotesis yang telah dirumuskan dan dijabarkan, maka dapat ditarik kesimpulan sebagai berikut :

1. Berdasarkan hasil dari pengujian (UJI F) Variabel variabel bebas yang melputi Jumlah Penduduk (JPD), Produk Domestik Regional Bruto (PRB) serta 
Upah Minimum Kabupaten/Kota (UMK) yang ada pada peneltian ini mempunyai pengaruh signifikan terhadap variabel dependen yaitu Tinngkat Pengangguran Terbuka. Melihat hasil dari penelitian berarti dapat dibuktikan bahwa hipotesis pertama bahwa semua variabel independen berpengaruh signifikan adalah dapat dibuktikan

2. Berdasarkan hasil dari Pengujian (UJI T) pada masing masing variabel bebas diperoleh hasil bahwa:

a. Variabel Jumlah Penduduk (JPD), secara parsial bepengaruh siginfikan terhadap Tingkat Pengangguran Terbuka (TPT) dengan hasil tersebut dapat simpulkan bahwa hipotesis kedua terbukti kebenerannya

b. Variabel Produk Domestik Regional Bruto (PDRB), secara parsial bepengaruhsiginfikan terhadap Tingkat Pengangguran Terbuka (TPT) dengan $\mathrm{h}$ asil tersebut dapat simpulkan bahwa hipotesis ketiga terbukti kebenerannya

c. Variabel Upah Minimum Kabupaten/Kota (UMK), secara parsial bepengaruh siginfikan terhadap Tingkat Pengangguran Terbuka (TPT) dengan $\mathrm{h}$ asil tersebut dapat simpulkan bahwa hipotesis keempat terbukti kebenerannya

Dari hasil dari penelitian yang telah dilakukakan oleh penulis dapat diambil suatu saran yang nantinya dapat membantu pemerintah daerah setempat sebagai bahan pertimbangan keputusan dalam suatu pengambilan kebijakan. Adapun saran yang dapat dikemukakan oleh penulis adalah sebagai berikut:

1. Hendaknya pemerintah membuat aturan tentang kemudahan pemberian akses kredit kepada masyarakat dalam meningkatkan pengembangan usahanya atau membuat usaha baru yang nantinya dapat membuka lapangan pekerjaan
2. Hendaknya pemerintah memperhitungkan aturan kenaikan upah disetiap periodenya dalam kaitannya untuk kesejahteraan masyarakat, bukan hanya pekerja saja tapi juga pemilik modal supaya perekonomian masyarakat tumbuh beriringan dan tidak terbebani satu sama lain

3. Pada penelitian yang akan datang tentang tingkat pengangguran terbuka diharapkan dapat melihat faktor faktor lain yang dapat menjadi bahan penelitian seperti indeks pembangunan manusia, pertumbuhan ekonomi, inflasi, yang berguna untuk membantu pemerintah daerah setempat dalam mengambil kebijakan tentang mengatasi masalah tingkat pengangguran terbuka di provinsi Jawa Timur

\section{Daftar Pustaka}

Mahroji, Dwi. dan Anwar, Saiful. (2020). Pengaruh Jumlah Penduduk, PDRB, dan Indeks Pembangunan Manusia (IPM) Terhadap Tingkat Penganguran di Provinsi Jawa Tengah. Jurnal ekobis: Ekonomi, Bisnis \& Manajemen Jakarta, 7 no.3, (2020): 48-57

Gilarso, T.SJ. Pengantar Ilmu Ekonomi Mikro. Yogyakarta: Kanisius, 2003

Purnami, Izatun. Pengaruh Tingkat Pendidikan dan Upah Minimum Kabupaten/Kota (UMK) Terhadap Penyerapan Tenaga Kerja di Provinsi Jawa Barat Tahun 2010-2013. (Bachelor Essay) Univesitas Islam Negeri Syarif Hidayatullah, Jakarta. Diunduh dari http://repository.uinjkt.ac.id/dspace/h andle/123456789/30167, 2015.

Jhingan, M.L. Ekonomi Pembangunan dan Perekonomian. Jakarta: PT. Raya Grafindo Persada, 2003.

Khoirulana. Penelitian Analisis Pengaruh Jumlah Penduduk, Produk Domestik Regional Bruto (PDRB), Upah 
Minimum Kabuppaten/Kota (UMK), dan Inflasi Terhadap Tingkat Pengangguran Terbuka di Provinsi Jawa Tengah Periode Tahun 20112015.( Bachelor Essay ) Universitas Muhammadiyah, Surakarta. Diunduh dari http://eprints.ums.ac.id/56486/1/NAS KAH\%20PUBLIKASI.pdf, 2017.

Kuncoro, Mudrajad. Ekonomika Pembangunan, Teori, Masalah dan Kebijakan. Yogyakarta: UPP STIM YKPN, 2006.

Muminin, M.Amirul., \& Rianto, Wahyu H. Pengaruh Pertumbuhan Ekonomi Dan Jumlah Penduduk Terhadap Tingkat Pengangguran Terbuka Di Kabupaten/Kota Provinsi Jawa Timur Tahun 2011-2015. Jurnal Ilmu Ekonomi Universitas Muhammadiyah Malang, 1 no.3, (2017): 374-384

Sukirno, Sadono. Makro Ekonomi Modern, Perkembangan Pemikiran dari Klasik Hingga Keynesian Baru. Jakarta: PT Raja Grafindo Persada, 2000.

Sukirno, Sadono. Mikro Ekonomi, Teori Pengantar. Edisi 3. Jakarta: PT Raja Grafindo Persada, 2005.

Sukirno, Sadono. Makro Ekonomi Teori Pengantar. Edisi 3. Jakarta: PT Raja Grafindo Persada, 2006. 